\title{
A note on language
}

Unless otherwise noted, all translations in this work are my own. The reader will notice that in some instances I have used words that to modern ears might sound insensitive. The words 'cripple', 'cripple-care', and even 'the disabled' are widely understood today as pejorative or insensitive terms, but during the time period which this study examines, they were not just common social and medical parlance, they were considered particularly important denotative terms. As other linguistic markers evolved during the war, many amputees fought loudly to retain the label of 'war-cripple' [Kriegskrüppel] because they resented being subsumed into the larger and less explicit category of 'war damaged' [Kriegsbeschädigte] or 'war invalid' [Kriegsinvalide]. To men who had lost their arms or legs, being 'lumped together' with the blind or the tubercular or the psychologically damaged was considered an insult and an elision of the significant bodily sacrifice that they had endured and which set them apart from other war disabled soldiers. 'War cripple' was a label that many claimed proudly and insisted upon being called. Out of respect for them, where appropriate, I have not modernised the instances in which this language was used for especial denotative purposes. In other instances, I have retained the more accurate, though perhaps anachronistic sounding, translations of 'the disabled' [Schwerbeschädigte] or 'the maimed' [Versehrte], when the language itself is revealing of historical attitude or phenomenon under discussion. Moreover, in translations of titles, names, organisations, and other official organs, I have also tried to remain historically true to the actual language that was used. 